\title{
The Role of Some Biochemical Parameters in The Formation of Gallstones
}

\author{
Ammar F. Najeeb Sakena H. Rashed \\ Department of chemistry, \\ college of Sciences, \\ Mosul university
}

$\begin{array}{lr}\text { Received } & \text { Accepted } \\ 6 / 3 / 2006 & 6 / 6 / 2006\end{array}$

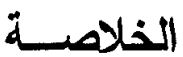

تناولت الدراسة (52) مريضاً مشخصاً بحصوات كيس العرارة غير العرضية. تم

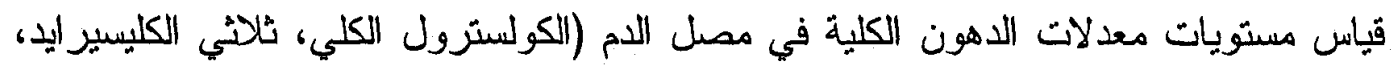

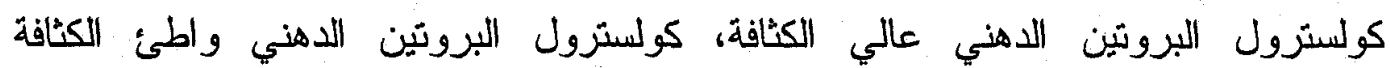

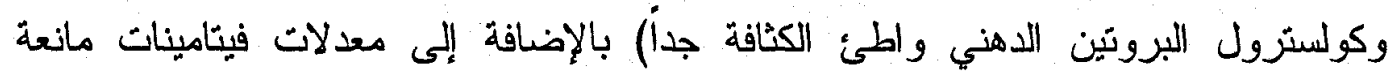

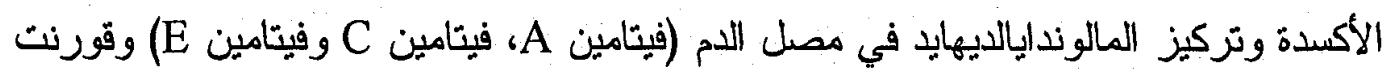
مع مجموعة سيطرة من (20) شخصباً سليماً. وضحت النتائج وجود ارتفاع معنوي في مستويات الكولسترول الكلي، ثلاثي

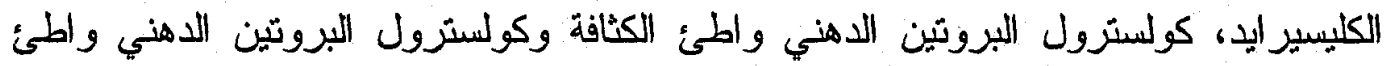

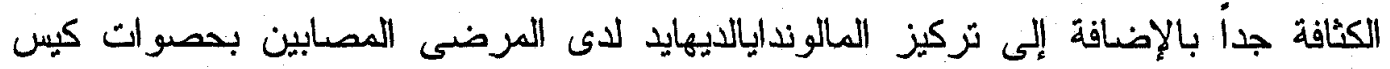

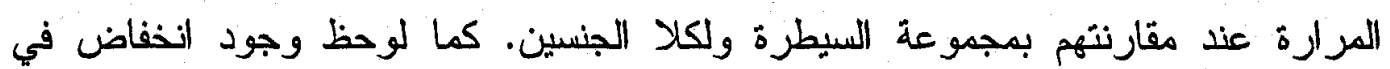

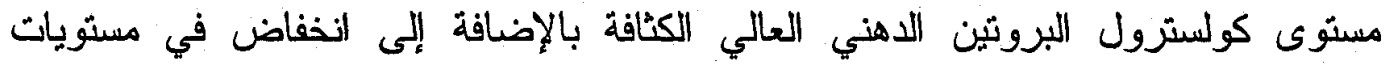

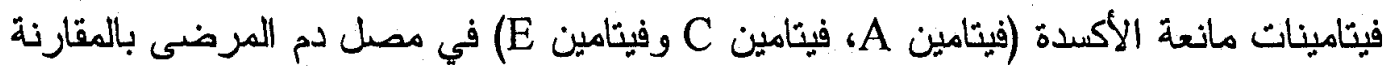

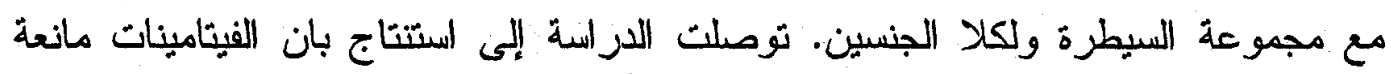

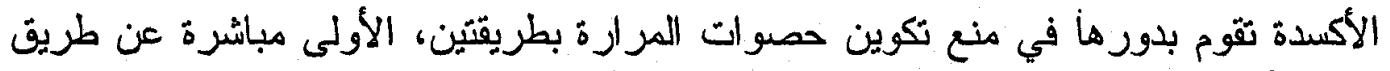

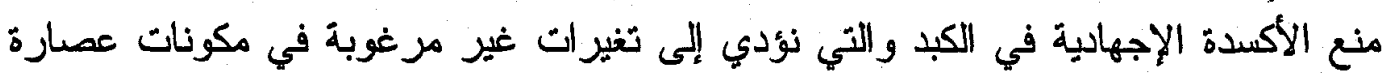

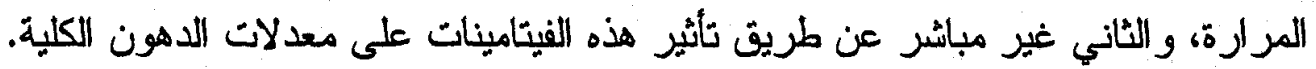




\section{ABSTRACT}

The study dealt with (52) patients diagnosed with asymptomatic gallstones. Serum lipid profile (total cholesterol TC, triglycerides TG, high density lipoprotein cholesterol HDL-C, Low density lipoprotein cholesterol LDL-C and very low density lipoprotein cholesterol VLDLC) as well as antioxidant vitamins (vitamin $A$, vitamin $C$ and vitamin $E$ ) and malondialdehyde were measured for them and were compared with a control group of (20) healthy individuals.

Results revealed a significant increase in TC, TG, LDL-C and VLDL-C as well as malondialdehyde concentration in the sera of the patients with gallstones when compared to control group for both sexes. A significant decrease in HDL-C as well as the antioxidant vitamins (vitamin A, vitamin C and vitamin $\mathrm{E}$ ) were detected in sera of the patients compared to control group for both sexes. The study reached to a conclusion that antioxidant vitamins play their role in the prevention of the formation of gallstones in two ways, the first is direct, by preventing the oxidation stress within the liver leading to unfavorable changes in the bile composition and the second way is indirect through their influence on lipid profile.

\section{Introduction}

Gallstones are crystalline structures formed by concretion or accretion of normal or abnormal bile constituents. These stones are divided into three major types, cholesterol and mixed stones account for 80 percent of the total, with pigment stones comprising the remaining 20 percent. Mixed and cholesterol gallstones usually contain more than 70 percent cholesterol monohydrate plus an admixture of calcium salts, bile acids and bile pigments, proteins, fatty acids, and phospholipids. Pigment stones are composed primarily of calcium bilirubinate; they contain less than 10 percent cholesterol ${ }^{(1)}$.

Bile plays a vital role in the metabolism of lipids in mammalians, whereas it is used as a shuttle to excrete cholesterol, bilirubin and a number of hormones and drugs. The liver excretes bile in the form of a diluted solution which contains (95-98\%) water, it is then converted to a concentrated solution of sodium and bile salts in the gallbladder ${ }^{(2)}$.

Gallstones can block the normal flow of bile if they lodge in any of the ducts that carry bile from the liver to the small intestine. That includes the hepatic ducts, which carry bile out of the liver; the cystic duct, which takes bile to and from the gallbladder; and the common bile duct, which takes bile from the cystic and hepatic ducts to the small intestine. Bile trapped in these ducts can cause inflammation in the gallbladder, the 
ducts, or, rarely, the liver. Other ducts open into the common bile duct, including the pancreatic duct, which carries digestive enzymes out of the pancreas. If a gallstone blocks the opening to that duct, digestive enzymes can become trapped in the pancreas and cause an extremely painful inflammation called gallstone pancreatitis ${ }^{(3)}$.

Cholesterol is excreted from the human body via bile with changing and as a cholesterol or after be modified to bile acids ${ }^{(4,5)}$. This approach is done by the integration between the hepatocytes and lipoproteins, whereas cholesterol is transferred from the body to the liver to be excreted to the bile by high density lipoprotein (HDL-C) ${ }^{(6,7)}$.

The aim of this study is to evaluate the role of lipids in the formation of gallstones and to determine whether antioxidant vitamins take part in the formation of such stones or not. by the measuring serum lipid profile and antioxidant vitamins in patients with gallstones and comparing the results with a control group of healthy individuals.

\section{Experimental}

Blood samples of (52) patients (23 male and 29 female) with asymptomatic gallstones were collected as well as a control group of (20) healthy individuals (10 male and 10 female) after a period of fasting ranged between (9-12) hours. The age of the patients ranged between (5060 ) years as in the control group too.

\section{Measured parameters}

\section{Serum Lipid Profile}

A. Total cholesterol (TC): was measured enzymatically ${ }^{(8)}$ using manufactured kit from (BioMerieux).

B. Triglycerides (TG): was measured enzymatically ${ }^{(9)}$ using a manufactured kit from (Labkit).

C. High density lipoprotein cholesterol (HDL-C): was measured enzymatically ${ }^{(10)}$ using a kit manufactured by (BioMerieux).

D. Low density lipoprotein cholesterol (LDL-C): it was calculated using the equation below ${ }^{(11)}$ :

$L D L-C=($ Total cholesterol $)-(H D L-C)-(T g / 5)$

E. Very low density lipoprotein (VLDL-C): it was calculated using the equation below ${ }^{(11)}$.

$V L D L-C=T g / 5$ 


\section{Serum Antioxidant vitamins}

A. Vitamin A (Vit. A): vitamin A was determined by UV. degradation of the vitamin which is measured at wavelength $(327 \mathrm{~nm})^{(12)}$.

B. Vitamin C (Vit. C): vitamin $\mathrm{C}$ was determined using 2,4-dinitro phenyl hydrazine (DNPH) method ${ }^{(13,14)}$.

C. Vitamin E (Vit. E): was determined using colorimetric method ${ }^{(15)}$.

3.Malondialdehyde (MDA): was measured using colorimetric method $^{(16)}$.

Statistical Analysis: T-test was used to determine the probability (P-value).

\section{Results and Discussion}

Results shown in table (1) demonstrate a significant increase in serum levels of (total cholesterol, triglycerides, VLDL-C and LDL-C) and a significant decrease in HDL-C level in patients with gallstones compared to control group for both sexes. This agrees with many studies ${ }^{(17,18)}$. Other studies focus on the elevation of triglycerides and the decline of HDL-C levels only. These studies demonstrates that high level of triglycerides may be the obstacle that retards cholesterol to be excreted from the bile and then its stagnation and crystallization to form the stones ${ }^{(19)}$. 
Table (1): Serum lipid profile levels for patients with gallstones and the control group

\begin{tabular}{|c|c|c|c|}
\hline Parameters & Sex & $\begin{array}{l}\text { Patients with } \\
\text { gallstones }\end{array}$ & Control group \\
\hline \multirow{2}{*}{$\begin{array}{c}\text { Total } \\
\text { Cholesterol } \\
(\mathrm{mg} / 100 \mathrm{ml})\end{array}$} & Male & $257.25^{* * *} \pm 15.0$ & $193.18 \pm 9.8$ \\
\hline & Female & $229.27^{* * *} \pm 9.1$ & $189.3 \pm 11.1$ \\
\hline \multirow{2}{*}{$\begin{array}{l}\text { Triglycerides } \\
(\mathrm{mg} / 100 \mathrm{ml})\end{array}$} & Male & $146.29 * * * \pm 29.7$ & $101.9 \pm 11.5$ \\
\hline & Female & $158.68^{* * *} \pm 14.1$ & $105.8 \pm 9.8$ \\
\hline \multirow{2}{*}{$\begin{array}{c}110 L-C \\
(\mathrm{mg} / 100 \mathrm{ml})\end{array}$} & Male & $23.70 * * * \pm 4.5$ & $42.27 \pm 3.6$ \\
\hline & Female & $25.97 * * * \pm 4.4$ & $42.6 \pm 5.5$ \\
\hline \multirow{2}{*}{$\begin{array}{l}\text { VLDL-C } \\
(\mathrm{mg} / 100 \mathrm{ml})\end{array}$} & Male & $29.25 * * * \pm 5.9$ & $20.38 \pm 2.3$ \\
\hline & Female & $31.73 * * * \pm 2.8$ & $21.16 \pm 1.9$ \\
\hline \multirow{2}{*}{$\begin{array}{c}\text { LDL-C } \\
(\mathrm{mg} / 100 \mathrm{ml})\end{array}$} & Male & $204.28 * * * \pm 17.2$ & $130.5 \pm 9.5$ \\
\hline & Female & $171.74 * * * \pm 11.7$ & $125.54 \pm 9.0$ \\
\hline
\end{tabular}

The data is expressed by mean \pm standard deviation

$\left({ }^{*} \mathrm{P}\right.$-value $\leq 0.01, * * \mathrm{P}$-value $\leq 0.001,{ }^{* * *} \mathrm{P}$-value $\left.\leq 0.0001\right)$

Further more evidence was obtained by the measuring serum antioxidant vitamins levels (vitamin A, vitamin C and vitamin E) as well as malndialdehyde as shown in table (2). The results show a significant decrease in antioxidant vitamins levels and an increase in malondialdehyde concentration for the patients compared to control group for both sexes, this agrees with the findings of many researchers ${ }^{(20)}$, who revealed a lack of these vitamins in the sera of patients with gallstones.

The researchers theorize that oxidant stress within the liver leads to unfavorable changes in bile composition that promote precipitation of both cholesterol and bilirubin (thus favoring the formation of both cholesterol and pigment stones). ${ }^{(21,22)}$ These findings corroborate earlier studies showing that antioxidant deficiencies can induce gallstone formation in animals ${ }^{(23,24)}$. 
Table (2): Antioxidant vitamins levels in the sera of the patients and the control group

\begin{tabular}{|c|c|c|c|}
\hline Parameters & Sex & $\begin{array}{c}\text { Patients with } \\
\text { gallstones }\end{array}$ & Control group \\
\hline \multirow{2}{*}{$\begin{array}{l}\text { Vitamin } \mathrm{A} \\
(\mathrm{IU} / 100 \mathrm{ml})\end{array}$} & Male & $163.7^{*} \pm 8.8$ & $171.45 \pm 5.2$ \\
\hline & Female & $163.37^{*} \pm 8.5$ & $174.8 \pm 7.7$ \\
\hline \multirow{2}{*}{$\begin{array}{l}\text { Vitamin C } \\
(\mu \mathrm{mol} / \mathrm{L})\end{array}$} & Male & $45.41 * * \pm 3.0$ & $53.09 \pm 4.6$ \\
\hline & Female & $38.2 * * \pm 5.4$ & $50.1 \pm 6.3$ \\
\hline \multirow{2}{*}{$\begin{array}{l}\text { Vitamin } E^{2} \\
(\mu \operatorname{mol} / \mathrm{L})\end{array}$} & Male & $10.22 * * * \pm 2.15$ & $17.82 \pm 2.85$ \\
\hline & Female & $12.76 * * * 3.5$ & $19.29 \pm 3.0$ \\
\hline \multirow{2}{*}{$\begin{array}{c}\text { Malondialdehyde } \\
(\mu \mathrm{mol} / \mathrm{I})\end{array}$} & Male & $2.43 * * * \pm 0.30$ & $0.16 \pm 0.07$ \\
\hline & Female & $2.33 * * * \pm 0.18$ & $0.15 \pm 0.08$ \\
\hline
\end{tabular}

The data is expressed by mean \pm standard deviation

(* P-value $\leq 0.01, * *$ P-value $\leq 0.001, * * *$ P-value $\leq 0.0001)$

From another aspect, vitamin $\mathrm{C}$ may be involved in the transformation of cholesterol to bile acids and thus prevent it from accumulation and precipitation in the bile to form stones ${ }^{(19)}$.

The decline of antioxidant vitamins in the sera of the patients may explain the rise in malondialdehyde, total cholesterol, triglycerides, LDL-C and VLDL-C as well as decrease of HDL-C and this corroborates many such findings ${ }^{(25,26,27)}$. This can be more clarified as shown in table (3).

Table (3): Pearson correlation between malondialdehyde and lipid profile parameters

\begin{tabular}{|c|c|c|c|c|c|}
\hline $\begin{array}{c}\text { Pearson } \\
\text { correlation }\end{array}$ & $\begin{array}{c}\text { Total } \\
\text { cholesterol }\end{array}$ & Triglycerides & HDI-C & LDL-C & VLDI-C: \\
\hline \begin{tabular}{l} 
R values \\
\hline
\end{tabular} & $0.0003^{* *}$ & $0.007^{*}$ & $0.005^{*}$ & $0.0009^{* *}$ & $0.007^{*}$ \\
\hline
\end{tabular}

${ }^{*}$ Correlation is significant at $\mathrm{P} \leq 0.01$

${ }^{* *}$ Correlation is significant at $\mathrm{P} \leq 0.001$ 
The results demonstrate that malondialdehyde, (which is considered as a marker for the oxidation stress) ${ }^{(28)}$, is directly proportional to the total cholesterol, triglycerides, LDL-C and VLDL-C. whereas it is inversely proportional to HDL-C levels.

The lack in antioxidant vitamins may lead to the oxidation of lipoproteins in which these particles may lose their function as a carrier of lipids ${ }^{(29)}$. This oxidation can take place on their apoproteins. LDL particles undergo oxidation on their apoprotein $\mathrm{E}$ and so they become unidentified by their receptors on the cells leading to their aggregation and finally the elevation of serum LDL and its content of cholesterol ${ }^{(30)}$.

The oxidation of HDL particles can occur on their apo A-I and Apo A-II, or on lecithin: cholesterol acyl transferase (LCAT) enzyme and this leads to the decline in HDL-C levels ${ }^{(5)}$.

The rise in the levels of triglycerides and VLDL-C concomitant with the decrease of antioxidant vitamins may be attributed to the oxidation of lipoprotein particles, or to the oxidation of cellular lipoprotein lipase (LPL) which is responsible for triglycerides hydrolysis to free fatty acids and glycerol ${ }^{(1,5)}$.

Finally antioxidant vitamins play their role in the prevention of the formation of gallstones in two ways, the first is direct, by preventing the oxidation stress within the liver leading to unfavorable changes in the bile composition and the second way is indirect through their influence on lipid profile. 


\section{REFERENCES}

1. Norton J. G. and Kurt J. I. (1998). "Diseases of The Gallbladder and Bile Ducts" cited in Harrison's principles of internal medicine" on CD-ROM, $14^{\text {th }}$ ed., McGraw Hill Company, USA.

2. Marlow, L.S.; Sherlock, D.S., (1981). "Surgery of the gall bladder and bile ducts", $2^{\text {nd }}$ ed., Butterwork and Co. (Publisher) Ltd., Pp.66-94.

3. National Digestive Diseases Information Clearinghouse (NDDIH) (2004), "Gallbstones" NIH publications, No. 05-2897 cited in: (http://www.digestive.niddk.nih.gov/ddiseases/pubs/gallstones)

4. Zubay, G., (1993), "Biochemistry", $3^{\text {rd }}$ ed., W.M.C. Brown publisher, Pp. 637.

5. King, M.W. (2004), "The Medical Biochemistry Page", (http://www.Indstate.edu/thcme/mwking/home.html).

6. Levy, R.I., (1980), "The structure, function and metabolism of HDL", circulation, 26(4):48.

7. Montegomery, R.; Conway, T.W.; Spector, A.A. and Chapell, D., (1996), "Biochemistry: A case oriented-approach", $6^{\text {th }}$ ed. Mosby-Year Book Inc. USA., Pp.356-388.

8. Ritchmod, J., (1973), "Preparation and properties of a cholesterol oxidase from norcardia $\mathrm{Sp}$. And its application to the enzymatic assay of total cholesterol in serum", Clin. Chem.19(12):1350-1356.

9. Postale, A.D. and Goodland, F.C., (1978), "Comparison of three automated methods of triglyceride analysis", Am. Clin. Bio. Chem. 15:18-24.

10.Kostner, G.M, (1976), "Enzymatic determination of cholesterol in high density lipoprotein fraction prepared polyanion precipitation", Clin. Chem.,22(5): 695.

11.Teitz, N.W. (1987) "Fundamental of clinical chemistry", $3^{\text {rd }}$ ed., W.B. Saunders Co., Pp. 448-481.

12. Wootton I.D.P. (1974), "Microanalysis in Medical Biochemistry", $5^{\text {th }}$ ed., Churchill Livingstone, Edinburgh and London.

13. Colowick S.P. and Kaplan N.O. (1979), "Methods in Enzymology", Vol. 62, part D, Academic Press Inc., USA.

14.Tietz N.W. (1994),"Textbook of Clinical Chemistry", W.B. Saunders Company, USA, A Division of Harcourt Brace and Company, Philadelphia.

15.Varley H.,. Gowenlock A.H. and bell M. (1976), "Practical Clinical Biochemistry: Hormones, Vitamins, Drugs and Poisons", $5^{\text {th }}$ ed., Vol. 2, William Heinemann Medical Books Ltd., London.

16.Beuge J.A. and Aust S.D. (1978). "Estimation of serum malondialdehyde level". Methods in Enzymology., Academic press, London, 51: 302. 
17.Finlayson, N.D.C.; Hays, P.C.; Simpson, K.J., (1999), "Diseases of the liver and biliary system", in: Davidson principles and practice of medicine, $18^{\text {th }}$ ed., edited by Christopher haslett, Pp. 683-736.

18.Hays, P.C.; Mackay, T.W.; Forrest, E.H. and Fisken, R.A. (2002), "Churchill's pocketbook of medicine", $3^{\text {rd }}$ ed., Churchill Livingstone Publications, Pp. 128-131.

19. Simon, H. (2004), "Gallstones and Gallbladder Disease", Harvard Medical School cited in (http://www.morehead.org/wellconnected/000010.html).

20.Berndtson, K. (2000), " Supplement Recommendations for Gallstones", cited in

(http://www.wholehealthmd.com/print/view/1,1560.RA 467 supp,00.html)

21.Violi, F.; Micheletta F. and Iuliano, L. (2002), "Antioxidants and Atherosclerosis", European Heart Journal supplements 4: 17-21.

22.Adams, K.A.; WERMUTH, E.O. and MCBRIDE, P.E. (1999), "Antioxidant Vitamins and the Prevention of Coronary Heart Disease", American Family Physician, 60: 3.

23. Worthington, H.V. (1997), "A pilot study of antioxidant intake in patients with cholesterol gallstones", Nutrition,13(2):118-27.

24.Braganza, J.M. (1995), "A radical view of gallstone aetiogenesis", Med Hypoth, 45:510-6.

25.Jenkins, S.A. (1977), "Hypovitaminosis C. and cholelithiasis in guinea pigs", Biochem. Biophys. Res. Comm., 77:1030.

26.Malet P.F. (1985), "Animal models of gallstone formation" In: Cohen S, Editor. Gallstones. Edinburgh: Churchill Livingstone;. Pp. 309-33.

27.Prasad K and Kalra J. (1993) "Oxygen free radicals and hypercholesterolemic atherosclerosis: effect of vitamin E", Am Heart J. 1993 Apr;125(4):958-73.

28.Annuk M., Zilmer M., Lind L. and Fellstrom B. (2001). "Oxidative stress and endothelial function in chronic renal failure". J. Am. Soc. Nephrol., 12: 2747-2752.

29.Mark, A. A.; Amy, G., Raj, U. and Hilary, J. P. (2005), " Oxidative Susceptibility of Unfractionated Serum or Plasma: Response to Antioxidants in Vitro and to Antioxidant Supplementation", Clinical Chemistry, 51:2138-2144.

30.Irit, M.; Tony, H.; Raymond, C. and Michael A. (1997), " Plasma LDL Oxidation Leads to Its Aggregation in the Atherosclerotic Apolipoprotein E-Deficient Mice", Arteriosclerosis, Thrombosis, and Vascular Biology. 17: 2995-3005. 